\title{
The Menace of Avoidance of Blood Transfusion: Time to Break the Silence
}

\author{
Babatunde 0 Akinbami* \\ Department of Oral and Maxillofacial Surgery, Nigeria \\ *Corresponding author: Babatunde O Akinbami, Department of Oral and Maxillofacial Surgery, Nigeria
}

\begin{tabular}{|c|c|}
\hline ARTICLE INFO & ABSTRACT \\
\hline Received: February 05, 2019 & Citation: Babatunde O Akinbami. The Menace of Avoidance of Blood Transfusion: Time to \\
\hline Published: 㓞 February 13, 2019 & Break the Silence. Biomed J Sci \& Tech Res 14(3)-2019. BJSTR. MS.ID.002557. \\
\hline
\end{tabular}

\section{Short Communication}

Medical science has established that acute severe blood loss from trauma, surgery or peripartum can mainly be treated by blood transfusion, but over the years some religious groups have vehemently refused such treatment for themselves, wives, children and other relations even in the face of death. Such indoctrinations stem from the fact that blood represent life and should not be taken from anyone and neither should it be given to even a dying patient. To proffer their own solutions to remedy blood loss, such groups have advocated the use of various blood products such as plasma expanders, colloids, crystalloids and even blood forming hormones like erythropoietin in place of blood replacement therapy. However, in instances of severe blood loss, most of these options including, use of diathermy machines, haemostatic agents; immediate bleeding followed by haemodilution and autotransfusion may not be enough and the clinician is faced with the dilemma of keeping the patient alive or watching such patient die against his/her Hippocratic oath. A few surgeons have lost their certificates due to lack of unifying policies that could defend and protect them against litigations that arose during practice. Therefore, I am proposing that it is high time the silence is broken.

The World Health Organisation should adopt concrete policies to guide and protect practitioners. In the scenario of a patient that needs urgent blood transfusion but refuses blood, what should the doctor do? If the patient is under general anaesthesia or unconscious, can the doctor decide to give blood? If blood is given, will the doctor be applauded for saving such life? or if he is sued for violating religious beliefs, will he be protected, are there policies that will protect him? knowing fully well that it is possible for such patients or relatives in some climes to even make gains from a cli nician who take decisions to transfuse. Should the clinicians watch such patients die and possibly face litigations and penalties. Therefore, there must be Universal Health policies adopted on such issues, because until now, decisions have been left to the discretion of the clinicians and some health care centres and countries do not even have standard operating procedures on matters of this magnitude and global impact. There has been a lot of articles in several journals supporting bloodless medical/surgical practice and alternatives to blood transfusion, no doubt it is possible to perform several complex surgeries including open heart surgeries, orthopaedic and gynaecological surgeries as documented in many articles by many surgeons but what of in a situation of severe blood loss during childbirth or severe trauma, no article has been documented to reflect the effectiveness of such blood alternatives or products in such situations, in addition, there is hardly any report on the number of deaths from bloodless surgeries and surgical emergencies. It has also been claimed that blood transfusion does not necessarily save a patient or the failure to transfuse makes a patient to die but such claims are not scientific. However, the issue under consideration is, if litigation occurs, what happens to the doctor who refuses to administer that which can or will save a patient in a scenario that the patient dies, and post-mortem reveals cause of death to be organ failure from severe blood loss, especially when there are no clearly defined policies on such matters in the institution of practice.In conclusion, the question is, apart from signing consent, what should be done in cases of severe blood loss to a patient who refuses blood transfusion and how is the clinician protected in case of any eventuality. I suggest a symposium can be held and followed up by formation of a joint committee that will brainstorm and arrive at final decisions. 


\section{ISSN: 2574-1241}

DOI: 10.26717.BJSTR.2019.14.002557

Babatunde 0 Akinbami. Biomed J Sci \& Tech Res

(c) (i) This work is licensed under Creative

Submission Link: https://biomedres.us/submit-manuscript.php

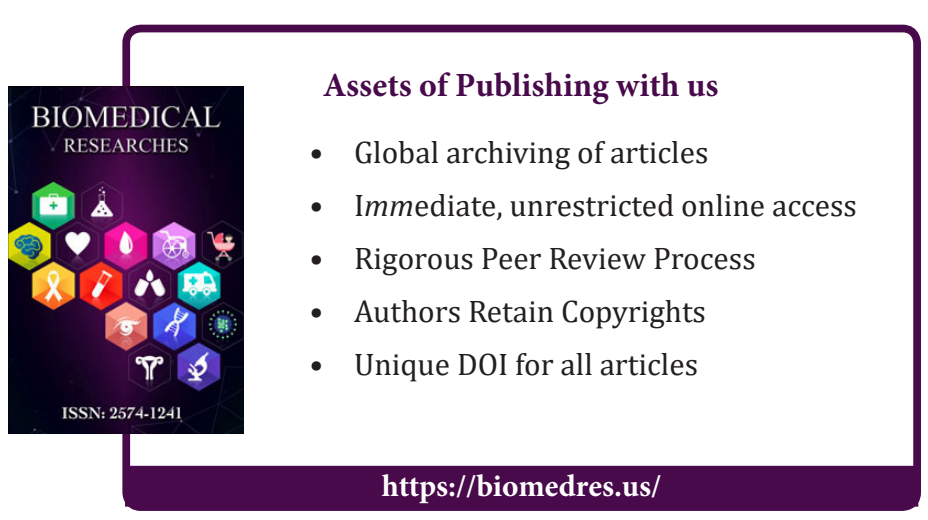

